\title{
The Analysis of Customer Satisfaction Post Covid-19
}

\author{
Handry Sudiartha Athar* \\ Postgraduate \\ University of Mataram \\ Mataram, Indonesia \\ handrysudiartha@gmail.com
}

\author{
Prayitno Basuki \\ Faculty of Economics and Business \\ University of Mataram \\ Mataram, Indonesia \\ prayitno.basuki.1962@gmail.com
}

\author{
Budi Santoso \\ Faculty of Economics and Business \\ University of Mataram \\ Mataram, Indonesia \\ santoso.hebato.budi@gmail.com
}

\begin{abstract}
This study aims to determine the effect of Trust in Brand, Promotion Mix, Service Quality to Customer Satisfaction at Lotte Mart Branch Mataram post the pandemic of Covid-19. This research is quantitative. In this study, the population is consumers who have made purchases of products at Lotte Mart for the last 6 months with the whole sample is as much as 100 respondents. Data used in this research is both primary and secondary. Data were collected by questionnaire and interviews, and analyzed by adapting multiple linear regression data using SPSS Program. The results showed that; 1) Trust In Brand has a positive and significant impact on Customer Satisfaction at Lotte Mart Branch Mataram post Covid-19; 2) Promotion Mix has a positive and significant impact on Customer Satisfaction at Lotte Mart Branch Mataram post Covid-19; 3) Service Quality has a positive and significant impact on Customer Satisfaction at Lotte Mart Branch Mataram post Covid-19. Based on the study findings, it is suggested that to increase customer satisfaction, Lotte Mart Lombok should improve the quality of service to consumers.
\end{abstract}

Keywords - trust in brand, promotion mix, service quality, post-covid-19, customer satisfaction.

\section{INTRODUCTION}

Retail competition is becoming increasingly competitive nowadays, and every company must continue to use creative and innovative strategies. Several major retail companies can be found in almost every region, including Lotte Mart. Lotte Mart is part of the Lotte Group and is one of the hypermarkets that supplies various types of food products, clothing, toys, electronic goods, and other items [1]. Currently, Lotte Mart is also available in Lombok.

To survive, every company needs to understand the changes that are occurring and strive to increase consumer confidence, quality of service, and sales promotion strategies that can satisfy their customers, even under the current circumstances and after the Covid-19 pandemic.

There are several factors affecting customer satisfaction that can be used as a reference by the company, including trust in the brand, service quality, and promotion mix. A lot of research has been done into customer satisfaction with varying results. In this study, the authors describe several previous studies relevant to this research topic. Promotion and service quality influence customer satisfaction and service quality as the most dominant influence [2]. Product quality and price have a positive and significant effect, while promotion has a negative but not significant effect [3]. Promotion and quality of service together have a significant effect on customer satisfaction [4]. Value perception and trust have major impacts on customer satisfaction [5]. Service quality has a positive and significant dominant effect on customer satisfaction [6]. Product quality and service quality have positive and significant effects on customer satisfaction [7]. Brand confidence and customer satisfaction have a positive effect on customer loyalty [8]. Service quality, promotion, and aftersales service have a significant and joint effect on customer or consumer satisfaction, but partial after-sales service has no effect and is not significant [9]. Meanwhile, product quality has a positive and significant impact on customer satisfaction and brand loyalty [10].

Ballester and Aleman (2001) in Kiyani [8] argue that trust plays an important role in long-term repurchases and customer satisfaction. Kiyani, [8] also explained in their study that trust in a brand is a customer's commitment to a particular brand. Some factors that play an important role in establishing trust in brands are a) Brand predictability refers to the ability of customers to anticipate brand performance in different usage situations and is a factor that can increase trust (Lau and Lee (2000) in [11]; b) the Liking brand described by Ruffin and Molina [12] by analogy that to establish a relationship between the two parties (consumers and brands), one party just like the other; c) Brand competence refers to the ability of brands to solve customer problems and meet their needs; d) Brand reputation that can be created through advertising, public relations, quality of products or services; and e) Trust in the company, which can be interpreted as trust in companies that own the brand.

Kumar and Patra [13] explain that in a modern marketing strategy the promotional mix is a combination of five main instruments, consisting of advertising, personal sales, publicity, sales promotion, and direct marketing; as a strategy and approach to increase sales. Therefore, many companies always try to present attractive promotions with different promotional media.

The main goal of any company is to make a profit and increase the productivity of the company [14]. One way is to improve the quality of the service. Parasuraman, Zeithaml and Berry (1988), in Ivanauskiene and Volungenaite [15] define service quality as the difference between consumer expectations and product perceptions usually used as a way to improve a company's competitiveness.

Parasuraman (1988) in Gothabandi, [14] provides several indicators of service quality measurement, namely: a). Tangibles: i.e. customer needs that focus on goods and services, including physical facilities, equipment, employee performance, and other facilities. b). Trust (reliability): namely the provision of direct and satisfactory services. Trust is the ability to keep promises to respond to customers. c). 
Response (responsiveness), which is a policy to help customers and provide fast (responsive) and appropriate services by providing clear information. d). Insurance (assurance) given to customers who include capabilities, courtesy and reliability owned by employees of the company and free from risk. e). Security or protection (empathy), which is the ease of good communication and understanding of customer needs.

Hansemark and Albinson (2004), in Angelova and Zekiri, [16] define customer satisfaction as' a general customer attitude towards a service provider, or an emotional response to the difference between what customers expect and what they receive, in terms of fulfilling of certain needs, goals or desires. Angelova and Zekiri [16] also mentioned that customer satisfaction is what a customer feels after knowing or feeling a company's performance to meet their expectations.

The above diverse survey results are one of the reasons why this customer satisfaction survey was conducted. And because of the Covid-19 pandemic early this year, the authors conducted this study to test and analyze the impact of trust in brand, service quality, and promotional mix on customer satisfaction in Lotte Mart Lombok post Covid-19.

\section{METHODS}

This study is a quantitative study that aims to determine whether the factors of trust in brand, service quality and promotion mix influence customer satisfaction in Lotte Mart Lombok post covid 19. This research was conducted in June 2020. The population of this study were all customers of Lotte Mart Lombok. Because of the large population, the sample was determined by no less than 100 respondents who were involved in non-probability samples. Not every element in the population has the same probability or possibility to be chosen as a sample [17].

The data of the study consisted of primary data and secondary data. Primary data is data obtained directly from field studies of the intended respondent. In this case, respondents were asked to complete questionnaires without engagement with the subjective opinion of the researchers, while secondary data in the form of library research were collected from books and journals relevant to this research. The questionnaires were distributed to customers who shop directly at Lotte Mart Mataram. The questionnaire used a Likert scale of 1-5: Score 1 = Disagree entirely (STS), Score $2=$ Disagree $(\mathrm{TS})$, Score $3=\operatorname{Neutral}(\mathrm{N})$, Score $4=$ Agree $(\mathrm{S})$ and score $5=$ Strongly agree (SS)

Questionnaire technique is a data collection technique done by providing a series of questions or written statements to the respondent to answer [18], or data collection techniques by providing or disseminating a questionnaire in hopes of the answer to the list of questions [19].

Data analysis was commenced by calculating the average value of each respondent's answer, which was then grouped into class intervals with the number $=5$. According to Noor [19], the class interval can be calculated using the formula.

$$
\text { Interval }=\frac{\text { Highest Scores-Lowest Scores }}{\text { Number of Classes }}
$$

This study had an interval $=0.8$. This result was obtained from:

$$
\text { Interval }=\frac{5-1}{5}=0,8
$$

The interval value is used as a guide to determine the lower and upper limits of each class, and finally, the classes are used to enter the average of each variable to find out the results of the study. The category guidelines used are shown in Table I.

TABLE I. RESEARCH RESPONDENTS RESPONSE CRITERIA

\begin{tabular}{|l|l|l|l|l|}
\hline Category & Trust In Brand & Service quality & Promotion in Mix & Customer satisfaction \\
\hline$\leq 1,79$ & Very low & Very low & Not attractive & Not satisfied \\
\hline $1,80-2,59$ & Low & Low & Less attractive & Less satisfied \\
\hline $2,60-3,39$ & High enough & High enough & Quite interesting & Quite satisfied \\
\hline $3,40-4,19$ & High & High & Interesting & Satisfied \\
\hline$\geq 4,20$ & Very High & Very High & Very interesting & Very satisfied \\
\hline
\end{tabular}

Some instrument tests conducted in this study are a) a validity test, designed to indicate the volume of data in a questionnaire that will measure what will be accurately measured; b) reliability test is performed to test the interpretation of the items of the statement in the investigated tool, focusing on the consistency of the answers given. A variable can be declared reliable if it has a Crombach Alpha value > 0.6 ; c) The classic assumption tests performed in this study are tests of data normality, multicollarity and heteroscedasticity.

The data analysis technique used is multiple linear regression analysis. Multiple linear regression is used because there are two variables, namely the independent variable $\mathrm{X}$ and the dependent variable $\mathrm{Y}$, and then another $\mathrm{Y}$ value is calculated or searched based on the existing $X$ value.
Hypothesis tests are performed with the t-test and the determination of the coefficient (R2). The t-test is used to determine the magnitude of the influence of the independent variable Trust In Brand, Promotion Mix, and the quality of individual business services may explain the dependent variable customer satisfaction, while the coefficient of determination test (R2) is done to measure how much of the variation of the dependent variable is Satisfaction Customers (Y) can be explained by independent variables, namely trust in the brand, promotion mix, and service quality. The conceptual framework of the study is shown in Figure 1. 


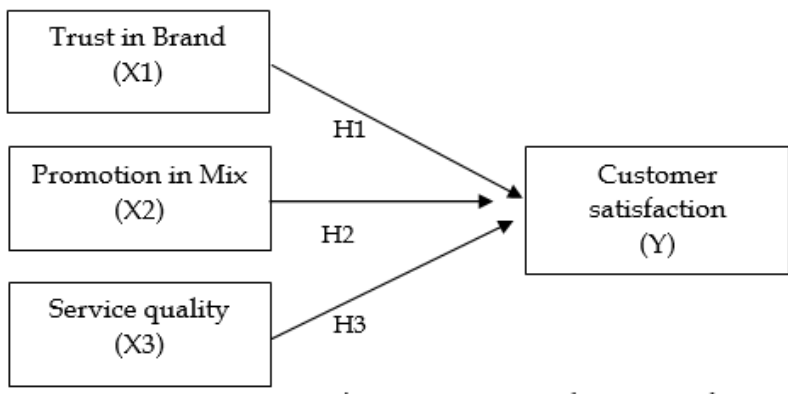

Fig. 1. Conceptual Framework

\section{RESULTS AND DISCUSSION}

Hypothesis testing in this study was conducted using the SPSS 16.0 program to analyze the relationship between the influence of Trust In Brand (X1), promotion mix (X2), and service quality (X3) on Lotte Mart Lombok Branch customer satisfaction (Y). The results of the study are shown in Table II, Table III, and Table IV.

TABLE II. TABLE 2. MULTIPLE REGRESSION RESUlTS

\begin{tabular}{|c|c|c|c|c|c|}
\hline \multirow{2}{*}{ Model } & \multicolumn{2}{|c|}{$\begin{array}{c}\text { Unstandardized } \\
\text { Coefficients }\end{array}$} & $\begin{array}{c}\text { Standardized } \\
\text { Coefficients }\end{array}$ & \multirow{2}{*}{ t } & \multirow{2}{*}{ Sig. } \\
\cline { 2 - 5 } & B & $\begin{array}{c}\text { Std. } \\
\text { Error }\end{array}$ & Beta & & \\
\hline (Constant) & 0.461 & 0.293 & & 1.575 & 0.119 \\
\hline X1 & 0.404 & 0.137 & 0.371 & 2.962 & 0.004 \\
\hline X2 & 0.272 & 0.097 & 0.229 & 2.795 & 0.006 \\
\hline X3 & 0.547 & 0.111 & 0.530 & 4.915 & 0.000 \\
\hline
\end{tabular}

TABLE III. T TEST RESULTS FOR MULTIPLE LINEAR REGRESSION

\begin{tabular}{|c|c|c|c|}
\hline Model & t & Sig. & Information \\
\hline (Constant) & 1.575 & 0.119 & \\
\hline X1 & 2.962 & 0.004 & Significant \\
\hline X2 & 2.795 & 0.006 & Significant \\
\hline X3 & 4.915 & 0.000 & Significant \\
\hline
\end{tabular}

TABLE IV. COEFFICIENT OF DETERMINATION

\begin{tabular}{|c|r|r|r|r|}
\hline Model & R & R Square & $\begin{array}{c}\text { Adjusted R } \\
\text { Square }\end{array}$ & $\begin{array}{c}\text { Std. Error of the } \\
\text { Estimate }\end{array}$ \\
\hline 1 & 0.825 & 0.681 & 0.671 & 0.245 \\
\hline
\end{tabular}

One hundred respondents consisted of 62 men and 38 women with age distribution of 35-45 years. 72 respondents in this survey have an income of $\geq 10$ million per month, while the other 28 respondents have an income of 5-10 million per month. With an average score of 4.56 with the value of 1 as the lowest level of trust in brands and the value of 5 as the highest level of trust in brands, it can be said that the majority of respondents answered with high confidence in the brand opposite Lotte Mart Lombok Branch.

In this study, the promotion in the mix is related to the consumer's perception of promotional media performed by the Lotte Mart Lombok affiliate when offering products from customers. The indicators for measuring the promotional mix variable used are 4 indicators according to Kotler and Keller [20] advertising, sales promotion, public relations, and personal sales. The results of this study receive an average score of 4.54, where the value of 1 as a very poor promotion level and the value of 5 as a very attractive promotion level. Thus, it can be concluded that the majority of respondents believe that the Lotte Mart Lombok Branch has a very attractive promotional mix.

The quality-of-service study is defined as a measure of how well the service level delivered can meet customer expectations in Lotte Mart, Lombok. Service quality variables are measured by indicators from Tjiptono, [21], namely: tangible; reliability; responsiveness, security, and empathy. The assessment results obtained service quality with an average score of 4.58, with a value of 1 as the lowest level of service quality and a value of 5 as the highest level of service quality. This can be interpreted to mean that the quality of service provided by the Lotte Mart Lombok Branch is highly appreciated by its customers even during the Covid-19 pandemic.

Customer satisfaction is the respondent's perception of feelings of pleasure or disappointment caused by the performance or results of a product being felt compared to his expectations of the 3 question items, the statement "The product performance of the Lotte Mart Lombok Branch is in line with my expectations" came with the highest answer score of 4.60. While "I am very satisfied with the use of Lotte Mart Lombok Branch products " gets a score of 4.49, Lotte Mart Lombok Branch's customer satisfaction is generally in the very satisfied category.

Based on table II, positive customer satisfaction of 0.461 means that customer satisfaction remains positive when there is no trust variable, promotion mix, and service quality. The regression coefficient of Trust In Brand (b1) has a positive value of 0.404 , which means that the higher the Trust In Brand of the customer, the higher the customer satisfaction. The regression coefficient of Promotion Mix (b2) is also positive 0.272 , which may explain that if the Promotion Mix (X2) variable is included in the model, customer satisfaction has increased by 0.272 . This positive regression coefficient of the promotion mix (b2) means that the more attractive the promotion mix, the higher the customer satisfaction. Conversely, the less attractive the promotion mix, the lower the customer satisfaction.

The Service Quality regression coefficient (b3), which is 0.547 , explains that if the service quality variable (X2) is included in the model, Customer Satisfaction has increased by 0.547 . This positive regression coefficient for service quality (b2) means that the higher the service quality, the higher the customer satisfaction. Conversely, the lower the quality of the service, the lower the customer satisfaction.

Based on the results of tests performed (Table III), results are obtained from hypothesis tests in the Trust In Brand variable, displaying the $t$ count value of 2.962 with a significance level of 0.004 greater than the value of $t$ table $(t(\alpha$ / 2) $(\mathrm{n}-2)=\mathrm{t}(0.05 / 2)(100-2)=\mathrm{t}(0.025,98)=\mathrm{t}$ table 1.984 with a significance value of 0.004 , then $\mathrm{Ho}$ is rejected and $\mathrm{Ha}$ is accepted. So, it can be concluded that the first hypothesis is that Trust In Brand has a significant impact on customer satisfaction on Lotte Mart Lombok Branch. These two variables are interrelated and in the same direction that Trust In Brand can improve customer satisfaction at Lotte Mart Lombok Branch. which means that the higher the Trust In 
Brand, the higher the customer satisfaction at Lotte Mart Lombok Branch.

The results of this study support the empirical study by Susilo [22], and Marlina [23], that brand confidence has a positive and significant effect on customer satisfaction. In this study, five indicators of brand confidence, namely brand predictability, brand competence, brand competence, brand reputation, confidence in Lotte Mart Lombok Branch business, responded positively by respondents and in the very high category. Widiyono and Pakkanna (2013) in Faradina and Satrio [2] explained that promotion is a technique or a variety of ways to sell products or messages that companies deliver to consumers about their products.

In this research, the promotional mix is reflected in advertising, sales promotion, public relations, and personal sales by Lotte Mart Lombok Branch. Based on the results of tests performed, results are obtained from testing the Promotion Mix variable hypothesis with a $t_{\text {count }}$ of 2,795 with a significance level of 0.006 greater than the value of $t$ table $(t$ $(\alpha / 2)(\mathrm{n}-2)=\mathrm{t}(0.05 / 2)(100-2)=\mathrm{t}(0.025,98)=\mathrm{t}_{\text {table }} 1.984$ with a significance value of 0.006 , then Ho is rejected and Ha is accepted. So, it can be concluded that the second hypothesis states that there is a significant positive effect of Promotion Mix on consumer satisfaction at Lotte Mart Lombok Branch.

These two variables are interrelated and unidirectional. Promotion Mix can affect consumer satisfaction at Lotte Mart Lombok Branch, which means that if the Promotion Mix becomes more attractive, customer satisfaction will increase.

The results of this study support the results of previous studies conducted by Faradina and Satrio [2], Setiawan [4], Ogi et al. [9], where the promotion has a positive effect on customer satisfaction. Likewise, empirical research conducted by Zain [6] in which promotion is the variable that has the most dominant influence on the formation of customer satisfaction. These results are inversely related to the study by Lenzun et al. [3] where the results of the study showed that promotion has a negative effect, but is not significant for customer satisfaction.

Based on the results of tests performed, results are obtained from testing the hypothesis that the service quality variable shows the value of $t_{\text {count }}$ of 4,915 with a significance level of 0.000 greater than the value of t table $(\mathrm{t}(\alpha / 2)(\mathrm{n}-2)=$ $\mathrm{t}(0.05 / 2)(100-2)=\mathrm{t}(0.025,98)=\mathrm{t}_{\text {table }} 1.984$ with $\mathrm{a}$ significance value of 0.000 then $\mathrm{Ho}$ is rejected and $\mathrm{Ha}$ is accepted. So, it can be concluded that the second hypothesis that there is a significant positive effect on the quality of service regarding customer satisfaction at Lotte Mart Lombok Branch. These two variables are interrelated and in the same direction indicates that the quality of service improves customer satisfaction at Lotte Mart Lombok Branch.

The results of this research support research conducted by Faradina and Satrio [2], Setiawan [4], Zain [6], Karuntu et al. [7], Ogi et al., [9], Sivadas and Baker-Prewitt, (2000) in Nam et al. [24] where service quality has a positive relationship with customer satisfaction.

Based on Table IV, the service quality is reflected in 5 indicators, namely: tangible, reliability, responsiveness, insurance, and empathy that describe the quality of service at Lotte Mart Branch Lombok. Of the five indicators, the reliability and empathy indicators have very high responses from research respondents.

In this study, the number $\mathrm{R}=0.825$ was obtained. This shows that there is a very strong correlation or relationship between the variables Trust in the brand (X1), Promotion mix (X2) and Service Quality (X3), to customer satisfaction contributing $82.5 \%$, i.e. a close relationship, the higher the $\mathrm{R}$ value then the relationship gets closer.

The value of $\mathrm{R}$ is known as 0.825 , then the determination coefficient ( $\mathrm{R}$ square) is $0.825 \times 0.825=0.681$, which means the ability of independent variables, namely trust in the brand (X1), promotion mix (X2), and service quality (X3). When explaining the variance of The Dependent Variable, customer satisfaction is $68.1 \%$. This means that there is a variance of $31.9 \%(100 \%-68.1 \%)$ of the dependent variable, explained by other factors not investigated.

While the figure Adjusted R Square $=0.671$ in the table shows that the ability of the independent variables, namely the variable Trust In Brand (X1), Promotion Mix (X2), and service quality (X3) contributed to customer satisfaction $67.1 \%$., while the rest $32.9 \%(100 \%-67.1 \%)$ is explained by other variables outside this study.

\section{CONCLUSION}

Trust in Brand has a positive and significant effect on Lotte Mart Lombok Branch's customer satisfaction, which means that during the Covid-19 pandemic, the greater consumers' confidence in them, the greater customer satisfaction when used of products from Lotte Mart Lombok Branch. Promotion Mix has a positive and significant effect on Lotte Mart Lombok Branch's customer satisfaction, even after Covid-19. This means that the more attractive the promotional mix is, the customer satisfaction will increase when using Lotte Mart Lombok Branch products, regardless the existence of the Covid-19 pandemic, as the needs of the consumer still need to be fulfilled. Service quality has a positive and significant effect on customer satisfaction in Lotte Mart Lombok Branch. This means that during the pandemic 19 pandemic, the higher the Quality of Service, the higher the customer satisfaction of consumers when using Lotte Mart Lombok Branch products.

\section{REFERENCES}

[1] www.lottemart.co.id. Accessed May, 2020

[2] F. Faradina and S. Satrio, "The Effect of Promotion and Service Quality on Customer Satisfaction at Alamanda Beautiful Homes," Indonesian College of Economics (STIESIA) Surabaya Journal of Management Science and Research, vol. 5, no. 7, 2016.

[3] L. Lenzun, M. Massie, and A. Adare, "The Effect of Product Quality, Price and Promotion on Telkomsel Prepaid Card Customer Satisfaction," EMBA Journal 1237, vol. 2, no. 3, pp. 1237-1245, 2014.

[4] S. Setiawan, Analysis of the Effect of Promotion and Service Quality on Customer Satisfaction (Case Study: "Waroeng Special Sambal Gonilan Branch - Surakarta"). Management Study Program, Faculty of Economics and Business, Muhammadiyah University, Surakarta: Scientific publications, 2014.

[5] S. Soegoto, Value Perception and Trust in Satisfaction and Its Impact on Consumer Loyalty. Manado: Faculty of Economics and Business, Management Department of Sam Ratulangi University, 2013.

[6] Z. Zain, "The Effect of Service Quality and Promotion on Speedy Instant Customer Satisfaction and Loyalty," JEAM, vol. 12, no. 1, 2013. 
[7] K. Karuntu, C. Christoffel, and N. Nia, "Product Quality and Service Quality Impact on Telkomsel Prepaid Card Customer Satisfaction," EMBA Journal, vol. 2, no. 3, pp. 1057-1067, 2014.

[8] K. Kiyani, "The Relationship between Brand Trust, Customer Satisfaction and Customer Loyalty," (Evidence from Automobile Sector of Pakistan) Interdisciplinary Journal Of Contemporary Research In Business, vol. 4, no. 1, 2012.

[9] O. Ogi, A. Adolfina, and R. Ruusen, "Service Quality, Promotion And After Sales Service Its Influence On Consumer Satisfaction of Honda Motorcycles Pt. Nusantara Surya Sakti in Amurang," EMBA Journal, vol. 2, no. 3, pp. 1603-1613, 2014.

[10] U. Urcaya and W. Wijaya, "Customer Satisfaction Mediates Product Quality and Fairness Prices Against Mcdonalds Brand Loyalty in Denpasar City. Faculty of Economics and Business, Udayana University (Unud), Bali, Indonesia," Eud Management Journal, vol. 6, no. 3 , pp. 2302-8912.

[11] S. Setyawan, A. Anton, A. Kussudiyarsana, dan I. Imronudin, "Brand Trust And Brand Loyalty, An Empirical Study In Indonesia Consumers,". British Journal of Marketing Studies vol. 4, no. 3, pp. 37-47, 2015.

[12] R. Rufín and C. M. Molina, "Moderating Effects of Familiarity and Experience in the Relationships of Trust with Its Antecedents and Consequences," e-Service Journal, vol. 9, no. 3, 19-42, 2014.

[13] S. Kumar, and P. Sidheswas, "Does Promotion Mix Really Help To Enhance Brand Equity: A Literature Review. Indian Journal Of Commerce \& Management Studies, vol. 8, no. 2, pp. 80, 2017.

[14] A. R. Ghotbabadi, S. Feiz, and R. Baharun, "Service Quality Measurements: A Review," International Journal of Academic Research in business and social sciences, vol. 5, no. 2, pp. 267, 2015.
[15] N. Ivanauskiene and J. Volungenaite, "Relations between Service Quality and Customer Loyalty: An Empirical Investigation of Retail Chain Stores in Emerging Markets," American International Journal of Social Science, vol. 3, no. 2, pp. 113-120, 2014.

[16] B. Angelova and J. Zekri, "Measuring Customer Satisfaction with Service Quality Using American Customer Satisfaction Model (ACSI Model), International Journal of Academic Research in Business and Social Sciences, vol. 1, no. 3, pp. 232, 2011.

[17] S. Siregar, Quantitative Research Methods Completed with Comparison of Manual and SPSS Calculations. Jakarta: Kencana, 2014

[18] S. Sugiyono, Statistika untuk penelitian. Bandung: Alfabeta, 2014.

[19] J. Noor, Research methodology. Jakarta: Kencana, 2015.

[20] K. Kotler and K. Keller, Marketing Management. Issue 12. Jakarta: Erlangga, 2012.

[21] F. Tjiptono, Marketing Strategy, ed. 3: Yogyakarta, Andi, 2012.

[22] H. Susilo, A. T. Haryono, and M. Mukery, "Analysis of the Effect of Price, Service Quality, Promotion and Trust on Consumer Satisfaction with the Decision to Visit as Intervening Variables in the Amanda Hills Bandungan Hotel," UNPAND Business Journal, pp. 1-20, 2017

[23] S. Marlina, "Analysis of the Effect of Product Quality, Promotion, Brand Trust, and Consumer Satisfaction on Purchasing Decisions on Honda Vario Motorcycles," Batanghari University Scientific Journal, vol. 18 , no. 1, pp. 16-125, 2018.

[24] J. Nam, Y. Ekinci, and G. Whyatt, "Brand equity, brand loyalty and consumer satisfaction, Annals of tourism Research, vol. 38, no. 3,pp. 1009-1030, 2011. 